\title{
ASMENŲ, TURINČIŲ REGĖJIMO SUTRIKIMŲ, REABILITACIJOS GALIMYBĖS
}

\author{
Ugnė Žilinskaité ${ }^{1}$, Lina Varžaityte் ${ }^{2}$ \\ ${ }^{1}$ Lietuvos sveikatos moksly universiteto Medicinos akademija, \\ ${ }^{2}$ Lietuvos sveikatos moksly universiteto Reabilitacijos klinika
}

Raktažodžiai: prastas regėjimas, prastos regos gerinimo reabilitacija, tendencijos akių reabilitacijoje, akių ligų reabilitacija.

\begin{abstract}
Santrauka
Tyrimo tikslas - atrinkti ir išanalizuoti mokslines publikacijas, kuriose vertinamos reabilitacijos galimybès, itaka ir nauda asmenims, turintiems regejimo sutrikimų. Medžiaga ir metodai - duomenys apie regejjimo sutrikimu turinčiu asmenu reabilitacijos galimybes ir regejjimo pagerejjimą po taikytos reabilitacijos buvo surinkti iš naujausių literatūros šaltinių bei joje aprašytų atvejų. Naudotasi PubMed duomenų bazių paieškos sistema pagal raktažodžius: low vision, low vision rehabilitation, tendency in vision rehabilitation, eyes diseases rehabilitation. Rezultatai - iš analizuotu atveju matyti, kad prastos regos gerinimas reabilitacijos būdu yra veiksmingas. Teigiamų rezultatų sulaukta ịvairaus amžiaus sergančiujų grupése. Matyti, kad artimajam ir tolimajam matymui gerinti naudojamos skirtingos reabilitacijos priemonès, tačiau skirtinguose centruose naudojamos panašios. Naudojamos tiek paprastos, elementarios priemonès, kaip dideliu šriftu knygos ar žurnalai, buitinès ,,priemonès“, padedančios prastai matančiajam lengviau apsitarnauti buityje, tiek sudėtingos kompiuterizuotos optinès sistemos, reikalaujančios specialaus profesionalų apmokymo. Po reabilitacijos ypač pagereja asmenų gebejjimas skaityti, t.y. matymas iš arti, taip pat gereja periferinis matymas, esant sutrikusiam centriniam matymui (dažniausia to priežastis amžinè geltonosios dèmès degeneracija tarp pagyvenusiujų). Išvados - asmenims, turintiems regos problemų, reabilitacijos priemonès yra veiksmingos, nepriklausomai nuo amžiaus. Efektyviausios yra periferinio matymo gerinimo reabilitacijos programos.
\end{abstract}

\section{Ivadas}

Literatūroje nurodoma, kad asmenys, turintys regos sutrikimų arba tiesiog prastai matantieji, yra tie, kurių regè- jimo aštrumas 6/21 ir kuriems regèjimo negerina akiniai ar kontaktiniai lęšiai, tačiau teigti, kad asmenys su „aštresniu“ regèjimu neturi regos problemų ir jiems nereikalingas gydymas būtų neteisinga [1]. Pvz., nepaisant teigiamo efekto, t.y. matymo pagerejiimo gydant amžinę geltonosios dèmès degeneraciją (viena iš pagrindinių ligų, sąlygojančių regèjimo netekimą vyresniems nei 55 metų asmenims) vaistų injekcijomis ị stiklakūnį, periferinis pacientų matymas išlieka nepakankamas, tačiau pasitelkus ịvairias šiuolaikines reabilitacijos priemones ir metodikas ar net paprastą sensorikos bei motorikos gerinimą, galima ženkliai pagerinti pacientu regèjimą ir ypač gebėjimą skaityti $[3,4]$. Todèl pacientų regos gerinimui, kaip vienas iš gydymo metodų, turètų būti ir reabilitacija, kadangi po jos ne tik pagerèja pacientų rega, bet ir mobilumas, gebejjimas apsitarnauti $[2,22]$.

Literatūroje aprašoma nemažai atvejų, kai po reabilitacijos, skirtos pagerinti sergančiųų regejjimą, buvo sulaukta teigiamo efekto $[5,6]$. Nepaisant to, vis dar trūksta informacijos sergantiesiems apie regos gerinimo galimybes [8]. Kad būtų pasiektas bendras tikslas - asmuo gautų ir žinotų visas įmanomas regos gerinimo metodikas - reikia gydytoju tarpusavio bendradarbiavimo, kad prireikus po tradicinio gydymo būtų paskirta reabilitacija [7].

Tyrimo tikslas - atrinkti ir išanalizuoti mokslines publikacijas, kuriose vertinamos reabilitacijos galimybès, įtaka ir nauda asmenims, turintiems regos sutrikimų ir kuriems regos negerina ịprastiniai gydymo metodai.

\section{Metodologija}

Buvo atlikta aprašomoji analizè. Literatūros paieška atlikta 2018 m. gruodžio mèn. naudojant PubMed duomenų bazių paieškos sistemą. Paieškai atlikti pasitelkti šie raktažodžiai ir jų deriniai: low vison, low vision and rehabilitation, tendency in vision rehabilitation, eyes diseases rehabilitation. Straipsniams iškelti tinkamumo kriterijai: straipsnis neturejjo būti senesnis nei 10 metų (toks laikotarpis pasirinktas dèl nepakankamo, ne senesnių nei 5 metai, straipsnių kiekio); 
straipsnyje turejo būti pateikiamas regos reabilitaciją nagrinejantis tyrimas. Taip pat buvo peržiūrimi mokslinių publikacijų literatūros šaltiniai, ne senesni nei 10 metų, kad būtų ịvertinta ir išanalizuota visa įmanoma naujausia medžiaga apie regos reabilitacijos tendencijas pasaulyje.

\section{Rezultatai}

Pagal nustatytus straipsnių tinkamumo kriterijus buvo atrinkti 5 straipsniai, nagrinėjantys atvejus apie reabilitacijos ittaką ir naudą asmenų su prastu regejimu regos pagerinimui. Visos publikacijos paskelbtos nuo 2009 metu.

Tyrimo duomenys surinkti Turkijoje, Indijoje, Jungtinėse Amerikos Valstijose. Tiriamosios grupès - regejimo sutrikimų turintys vaikai, suaugusieji bei vyresni nei 65 metų asmenys.

Regẻjimo pagerẻjimas vaikams, taikant reabilitaciją.

Indijoje atliktame tyrime dalyvavo 397 vaikai, lankęsi Haidarabado miesto regos gerinimo centre (Centre for Sight Enhancement (CSE) pietų Indijoje [11]. Tyrimo dalyvių amžiaus vidurkis buvo 11,9 metai ir daugiau nei pusè (57 proc.) visų tiriamųjų buvo berniukai.

Prieš tyrimą visų dalyvių regos būklę įvertinto gydytojas oftalmologas, jis tiriamiesiems nustate diagnozę. Daugiau nei pusè (55 proc.) prastai matančiųų sirgo tinklainès ligomis.

I tyrimą buvo įtraukiami ir gerai matantieji viena akimi, tačiau nebuvo įtraukiami vaikai, turintys psichinę ar protinę negalią. Nustatyti matymo sunkumus buvo pasinaudota anketa (LVP-FVQ II), kurią sudare 23 klausimai, kaip sunku vaikams ịžiūrèti, pvz., parduotuvių pavadinimus, autobuso numerị, kaip sunku žiūrèti televizorių, lankytis teatre dèl regos problemų ar kaip gerai, jų nuomone, jiems sekasi atlikti tokią pačia veiklą, kaip ir jų draugams ar bendraklasiams be regos sutrikimų. I kiekvieną klausimą vaikai galèjo atsakyti, kad jiems toje veikloje visiškai nekyla sunkumų, kad kyla šiek tiek sunkumų arba kyla daug sunkumų dèl regos atliekant tam tikrą veiklą. Pagal šios anketos rezultatus buvo pastebėta, kad daugelis vaikų dèl prastos regos patiria didelių sunkumur.

Tyrimo metu su vaikais dirbo ịvairių sričių specialistai, tokie kaip optometristai, vaikų edukatoriai, reabilitologai, instruktoriai, padedantys gerinti vaikų orientaciją bei mobilumą, informacinių technologijų specialistai, psichoterapeutai. Buvo taikytos regejjimo gerinimo reabilitacijos priemonės: rankinis monokuliarinis teleskopas, ant akinių pridedamas teleskopas, skliautiniai padidinamieji lęšiai, rankinis-kišeninis padidinamasis stiklas. Taip pat elektroninès priemonès: nešiojamas videodidintuvas, videokameros bei elementarios priemonès - skaitymo lempa, filtrai apsaugai nuo atspindžių ir siūlą i adatą padedantis ịverti ịrankis. Tokie kaip informacinių technologijų specialistai bei instruktoriai, padedantys gerinti vaikų orientaciją, labai prisidejjo prie darbo su sudètingomis reabilitacijos priemonèmis. Vaikams telefonuose buvo nustatomi priminimai, neleidžiantys pamiršti vizito ị šio tyrimo vykdymo centrą. Tyrimas truko 4 mènesius, manyta, kad per tokị laiką vaikai gebès ịsisavinti naujai pritaikomą regos gerinimo metodiką. Iš 397 tik 183 baigè pilną reabilitacijos kursą. Regejjimui ị tolị gerinti dažniausiai buvo naudotasi teleskopais. Edukatoriai vaikams taip pat aiškino, kaip dèl prastos regos lengviau prisitaikyti mokykloje, t.y. kad reikia sèsti ị pirmas eiles, rinktis geriau apšviestą vietą klasèje bei esant galimybei rinktis juodą arba baltą, o ne žalią, kaip ịprasta, lentą.

Po tyrimo, nepriklausomai nuo vaiko lyties, visiems tiriamiesiems buvo stebètas regejjimo pagerejjimas, ypač vyresniems nei 12 metų vaikams. Kad pasiekti geresni regéjimo rezultatai vèl nesuprastėtų, buvo rekomenduojama įsigyti ir naudoti namuose tyrimo metu turétas regejjimo gerinimo priemones.

Dar vienas tyrimas, vertinantis reabilitacijos naudą vaikams, atliktas Indijoje, šikart Delio mieste, šiaurés Indijoje [14]. Jame dalyvavo 92 pacientai nuo 6 iki 16 metų, apsilankę vienoje Delio regos gerinimo klinikoje per tyrimo vykdymo laikotarpi (6 ménesius). Vis dèlto visus tyrimo kriterijus: neturejo klausos ar intelekto sutrikimų, gebejjo atsakyti i jiems užduodamus klausimus ir atlikti jiems paskirtus regos testus - atitiko tik 35 vaikai. Prieš tyrimą vaikai buvo apžiūretti oftalmologo, tèvams buvo paaiškinta apie tyrimą ir jų vaikų regos būklę. Tyrime naudotos panašios kaip aukščiau aprašytuose tyrimuose regos reabilitacijos priemonès, kaip papildomos priemonès šiame tyrime dar buvo panaudotos dideliu šriftu ar paryškintu šriftu spausdintos knygos.

Buvo vykdyta anketinè apklausa, jos pagalba vertintas artimasis, tolimasis, spalvinis vaikų matymas bei akiplotis - klausimai atspindejjo kaip sunku vaikams atlikti tam tikras užduotis, susijusias su artimu, tolimu ar spalviniu matymu. Dažniausi sunkumai, su kuriais vaikai susidūre tyrimo metu dèl prasto regejjimo, buvo sunkumai mokykloje: matyti kas rašoma ant lentos, skaityti knygas iš ištiestos rankos atstumo bei rašyti tiesia linija. Po tyrimo buvo stebètas aiškus pagerejimas visose šiose veiklose, taip pat buvo pažymėtas ir psichoemocinès būklès pagerejjimas, t.y. vaikai geriau jautėsi tarp bendraamžių, lengviau integravosi į mokyklos bendruomenę ir netgi pasidarè lengviau apsitarnauti buityje, kas prieš tyrimą nebuvo išskirta kaip esminis faktas [14].

Regèjimo pagerẻjimas suaugusiesiems, taikant reabilitaciją. Tyrimas buvo atliktas stebint 28 JAV esančių centrų, teikiančių regos reabilitacijos paslaugą, darbą [12]. Tyrime dalyvavo 779 vyresni nei 18 metų asmenys. Buvo vykdyta anketinè asmenų apklausa prieš ir po tyrimo vyk- 
dymo laikotarpio (po 6-9 mėn.).Vertintas asmenų gebejjimas skaityti, gebejjimas apdoroti regimają informaciją, regejjimo motorinè funkcija. Šio tyrimo metu rega labai pagerèjo mažiau nei pusei (47 proc.) asmenų, kitiems pasiektas vidutinis regos pagerejjimas. Asmenys, kurių rega buvo 0,1, pasiekè geriausių regos pagerejjimo rezultatų.

Regẻjimo pagerèjimas senjorams, taikant reabilitaciją. Turkijoje atlikto tyrimo metu, kuriame dalyvavo 139 pacientai, vyresni nei 65 metai, su nustatytu regèjimo sutrikimu, kaip vienas iš tyrimo aspektų buvo nagrinejjama reabilitacijos įtaka pacientų regai [9]. Pacientams prieš tyrimą buvo nustatytas regejjimo aštrumas tiek žiūrint iš arti, tiek žiūrint iš toli, prieš tai įvertinus kiekvieno iš jų refrakcijos tyrimo rezultatus. Taip pat buvo įvertintas jų spalvinis matymas, išmatuoti akių spaudimai, apžiūrètas akių dugnas. Regejjimo gerinimui ị tolị naudotasi priemonèmis: Keplerio ir Galilèjo teleskopinès ir elektrooptinès sistemos, regèjimo gerinimui iš arti: telemikroskopinès ir elektrooptinès sistemos, didinamieji lęšiai, vaizdą didinantys akiniai (tvirtinami ant nuolatinių paciento akinių). Regèjimo aštrumas, regos lauko bei abiakis regejjimas buvo apskaičiuojamas Kestenbaum formule. Tyrimas truko 4 mènesius.

Didžioji dalis tyrime dalyvavusiujų sirgo amžine geltonosios dèmès degeneracija ir iš tyrimo tikejosi regos pagerejjimo žiūrint iš arti. Sergant amžine geltonosios dèmès degeneracija labiausiai nukenčia pacientų matymas iš arti, t.y. tokiems pacientams dèl centrinio matymo prastejjimo ar visiško jo netekimo sunku skaityti [10]. Tolimajam regejimui gerinti dažniausiai buvo naudotasi teleskopiniais lęšiais, nepaisant fakto, kad daugiau nei trečdaliui pacientų regos gerinimui buvo naudotasi daugiau nei viena priemone. Artimajam regèjimui gerinti daugiausia naudotasi vaizdą didinančiais akiniais. Akivaizdžių teigiamų rezultatų pasiekta abiem atvejais. Pacientų rega ị tolị po reabilitacijos vidutiniškai pagerejo nuo 0,125 iki 0,63 (kai geras matymas yra lygus $1)$, o matymas iš arti $(25 \mathrm{~cm})$ vidutiniškai nuo 0,25 iki 0,7 .

Daugiau nei 90 procentų dalyvavusiujų tyrime reabilitacijos metodus ir regos gerinimo priemones naudojo dar vienerius metus po tyrimo pabaigos - vadinasi, pacientams reabilitacijos metodai pasiteisino. Pacientai galèjo laisviau jaustis gatvèje dèl pagerẻjusio matymo ị tolị bei lengviau ịžiūrèti mažo šrifto raides skaitant, lengviau apsitarnauti buityje, pagerèjo ir jų gyvenimo kokybè.

Dar vienas tyrimas $(\mathrm{n}=624)$ buvo atliktas JAV [13]. Regos suprastèjimas vertintas kognityvinių funkcijų sutrikimų turintiems senjorams. Tyrimas truko pusmetị ir pagrindine prastos regos priežastis buvo amžinè geltonosios dèmès degeneracija. Duomenys vertinti pagal anketinius rezultatus. Asmenims taikytos skaitymo greiti gerinančios, tikslą pasiekti skatinančios bei atmintị gerinančios užduotys. Nors po tyrimo nebuvo stebėtas regos greičio pagerèjimas, asmenims vis dar kilo keblumų greitai surasti iš anksto numatytą tekstą knygoje, tačiau taikytos reabilitacijos priemonès pagerino asmenų greitị rašant tekstą, jis tapo aiškesnis.

\section{Rezultatų aptarimas}

Iš analizuotų tyrimų matyti, kad prastos regos reabilitacijos metodai ir priemonès yra naudingos ir reikalingos ìvairaus amžiaus asmenų grupèse. Tokio gydymo dẻka pagerejja ir asmenu gyvenimo kokybė $[25,26]$. Kadangi sergančiųų amžius nuo vaikų iki senjorų, todèl ir poreikiai bei regos aštrumas yra skirtingas bei individualus [16, 17, 29]. Kiekvienam sergančiajam galima ir netgi būtina pritaikyti individualią metodiką ir pratimus, nes tam yra sukurta ir adaptuota ịvairių prastos regos gerinimo metodų, padedančių pagerinti skaitymą ir orientaciją $[18,23]$. Nuo ganètinai paprastų: dideliu šriftu spausdinamų knygų ar laikraščių, garsinių, vadinamų kalbančiu prietaisų iki sudètingų kompiuterizuotų optinių sistemų [15]. Kadangi pasaulis vis modernèja, nuo naujų technologijų ir inovacijų neatsilieka ir regos pagerinimo reabilitacija [19]. Ateityje planuojama ịdiegti telereabilitaciją asmenims su prastu regèjimu, kai pacientai neišeidami iš namų galètų konsultuotis su gydytojais specialistais ir gauti patarimus, kaip pagerinti regèjimą konkrečiu atveju ar kur kreiptis dèl regejjimo gerinimo ar reabilitacijos pritaikymo galimybių [20].

Taikant reabilitaciją galima ženkliai pagerinti asmenų matymą, padèti jiems lengviau apsitarnauti buityje, išvengti atsitiktinių traumų, susijusių su regejjimo problemomis, ypač pacientams, kurie turi centrinio matymo pablogèjimą ar jo išnykimą, didelị dèmesị skiriant pagerinti periferinị matymą, kad tokiu būdu būtų kompensuotas centrinio matymo defektas $[21,24,27,28]$.

Deja, Lietuvoje regos gerinimo reabilitacijos būdu metodika nėra paplitusi, nèra tai aprašančių literatūros šaltinių ar vykdytų tyrimų.

\section{Išvados}

1. Asmenims, turintiems regos problemų, reabilitacijos priemonės yra veiksmingos, nepriklausomai nuo amžiaus.

2. Efektyviausios yra periferinio matymo gerinimo reabilitacijos programos.

\section{Literatūra}

1. Wilkinson ME, Shahid KS. Low vision rehabilitation: an update. Saudi Journal of Ophthalmology 2018;32(2):134-138.

https://doi.org/10.1016/j.sjopt.2017.10.005

2. Gothwal VK, Bharani S. Outcomes of multidisciplinary low vision rehabilitation in adults. Investigative Ophthalmology \& Visual Science 2015;56:7451-7461. 
https://doi.org/10.1167/iovs.15-16892

3. García-Layana A, Cabrera-López F, García-Arumí J. et al. Early and intermediate age related macular degeneration: update and clinical review. Clin Interv Aging 2017;12:1579-1587. https://doi.org/10.2147/CIA.S142685

4. Maniglia M, Cottereau BR, Soler V, Trotter Y. Rehabilitation approaches in macular degeneration patients. Front Syst Neurosci 2016;10:107.

https://doi.org/10.3389/fnsys.2016.00107

5. Wittich W, Canuto A, Overbury O. Overcoming barriers to low vision rehabilitation services: improving the continuum of care. Can J Ophthalmol 2013;48(6):463-7.

https://doi.org/10.1016/j.jcjo.2013.05.013

6. Binns AM, Bunce C, Dickinson C. et al. How effective is low vision service provision? A systematic review. Surv Ophthalmol 2012;57:34-65.

https://doi.org/10.1016/j.survophthal.2011.06.006

7. World Health Organization. International standards for vision rehabilitation: report of the international consensus conference, Rome, 9-12 December 2015. Moasca, Italy 2017.

8. Overbury O, Wittich W. Barriers to low vision rehabilitation: the montreal barriers study. Investigative Ophthalmology \& Visual Science 2011;52:8933-8938.

https://doi.org/10.1167/iovs.11-8116

9. Tunay ZO, İdil A, Petriçli IS, Özdemir Ö. Low vision rehabilitation in older adults. Turk J Ophthalmol 2016;46(3):118-122. https://doi.org/10.4274/tjo.68878

10. Christoforidis JB, Tecce N, Dell'Omo R, Mastropasqua R, Verolino M, Costagliola C. Age related macular degeneration and visual disability. Curr Drug Targets 2011;12(2):221-33. https://doi.org/10.2174/138945011794182755

11. Gothwal VK, Sumalini R, Bharani S. Assessing the effectiveness of low vision rehabilitation in children: an observational study. Investigative Ophthalmology \& Visual Science 2015; 56: 3355-3360.

https://doi.org/10.1167/iovs.14-15760

12. Goldstein JE, Jackson ML, Fox SM. et al. Clinically meaningful rehabilitation outcomes of low vision patients served by outpatient clinical centers. AMA Ophthalmol 2015;133(7):762-769. https://doi.org/10.1001/jamaophthalmol.2015.0693

13. Whitson HE, Whitaker D, Potter G, McConnell E. et al. A low vision rehabilitation program for patients with mild cognitive deficits. JAMA Ophthalmol 2013;131(7): 912-919.

https://doi.org/10.1001/jamaophthalmol.2013.1700

14. Ganesh S, Sethi S, Srivastav S, Chaudhary A, Arora P. Impact of low vision rehabilitation on functional vision performance of children with visual impairment. Oman J Ophthalmol 2013;6(3): 170-174.

https://doi.org/10.4103/0974-620X.122271

15. Turbert D. Low vision rehabilitation and low vision aids. American Academy of Ophthalmology 2018.
16. Chader GJ, Taylor A. Preface: the aging eye: normal changes, age related diseases, and sight saving approaches. Invest Ophthalmol Vis Sci 2013;54(14):ORSF1-ORSF4.

17. Ertekin YH, Tekin M, Uludag A, Arikan S, Sahin EM. Vision screening in children: is 7-9 years of age a threshold for visual impairment? Pak J Med Sci 2016;32(5):1194-1198.

https://doi.org/10.12669/pjms.325.10367

18. Trauzettel-Klosinski S. Current methods of visual rehabilitation. Dtsch Arztebl Int 2011;108(51-52):871-878.

https://doi.org/10.3238/arztebl.2011.0871

19. Trauzettel-Klosinski S. Current possibilities of visual rehabilitation. Ophthalmologe 2018;115(10):895-910.

https://doi.org/10.1007/s00347-018-0767-0

20. Bittner AK, Wykstra SL, Yoshinaga PD, Li T. Telerehabilitation for people with low vision. Cochrane Database Syst Rev 2015; 8: CD011019.

https://doi.org/10.1002/14651858.CD011019.pub2

21. Meyniel C, Bodaghi B, Robert PY. Revisiting vision rehabilitation. Front Syst Neurosci 2017; 11: 82.

https://doi.org/10.3389/fnsys.2017.00082

22. Wang BZ, Pesudovs K, Keane MC, Daly A, Chen CS. Evaluating the effectiveness of multidisciplinary low vision rehabilitation. Optometry and Vision Science 2012;89(9):1399-1408. https://doi.org/10.1097/OPX.0b013e3182678d82

23. Massof RW, Stelmack JA. Interpretation of low vision rehabilitation outcomes measures. Optom Vis Sci 2013 90(8): 788-798. https://doi.org/10.1097/OPX.0000000000000011

24. Harris J, Mizuiri D, Ambrus A, Lum FC. Vision rehabilitation preferred practice patterns. San Francisco CA: American Academy of Ophthalmology 2013: 1-41.

25. Lamoureux E, Pesudovs K. Vision specific quality of life research: a need to improve the quality. Am J Ophthalmol 2011;151:195-197, e192.

26. Rees G, Ponczek E, Hassell JB, Keeffe J, Lamoureux E. Psychological outcomes following interventions for people with low vision: a systematic review. Expert Rev Ophthalmol 2010;5:385-403.

https://doi.org/10.1586/eop.10.32

27. Donoghue OA, Ryan H, Duggan E. et al. Relationship between fear of falling and mobility varies with visual function among older adults. Geriatr Gerontol Int 2014;14:827-36 https://doi.org/10.1111/ggi.12174

28. White UE, Black AA, Wood JM, Delbaere K. Fear of falling in vision impairment. Optom Vis Sci 2015;92:730-5. https://doi.org/10.1097/OPX.0000000000000596

29. Barker L, Thomas R, Rubin G, Dahlmann-Noor A. Optical reading aids for children and young people with low vision. Cochrane Database Syst Rev 2015:CD010987.

https://doi.org/10.1002/14651858.CD010987.pub2 


\section{REHABILITATION FOR PEOPLE WITH LOW VISION \\ U.Žilinskaitè, L.Varžaitytė}

Key words: low vision, low vision rehabilitation, tendency in vision rehabilitation, eyes diseases rehabilitation.

Summary

Aim of this study - to find and analyse science publications where would be published about low vision rehabilitation and effectiveness of it. Methods - information about low vision rehabilitation programs and methods was searched and collected in the newest science publications. We used PubMed data base and key words like: low vision, low vision and rehabilitation, tendency in vision rehabilitation, eyes diseases rehabilitation. We also checked references from all publications. Results - after a lot of analysis we find out that low vision rehabilitation is really effective in all age groups. There were used different methods and means in both distance vision and near vision rehabilitation. But it was similar in different rehabilitation centres. There can be used quite simple gadgets like books printed in bolt or in bigger letters, things which make patients ' everyday life easier or even quite difficult electronical optical systems. After this kind of rehabilitation patients achieved success especially in reading and near vision also in peripheral vision abilities when they had problems with central vision loss (the main disease which affects it is age related macular degeneration). Conclusions - low vision rehabilitation is effective in all age groups of patients. The most effective are peripheral vision rehabilitation programs.

Correspondence to: ugnzil@gmail.com

Gauta 2019-03-18 